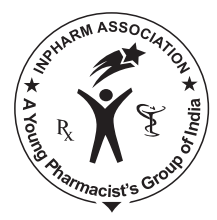

\title{
Protective Action of Flavonoids Genistein and Gingerol against Cisplatin Toxicity In Vitro
}

Sir,

Cisplatin is a platinum-based chemotherapy drug used for treating cancers and has proved to be toxic in earlier studies. Cisplatin has a number of side effects that can limit its usage. Many agents have been shown to ameliorate cisplatin toxicity. ${ }^{[1]}$ Genistein is an antioxidant isoflavone found in many plants as well as animal cells, soybeans, and soy products being a major source. Gingerol is the active constituent of fresh ginger and a proven antioxidant. Genistein and gingerol have been reported for their antigenotoxic and antimutagenic potential in cultured human lymphocytes. ${ }^{[2]}$ The earlier reported toxicity of cisplatin, the antimutagenic action of genistein and

gingerol, provided the basis for this study in the presence of metabolic activation to assess the effective dose level.

Human lymphocyte culture of two healthy donors was carried out. ${ }^{[3]}$ Later, metaphases were examined for different types of aberrations. For sister chromatid exchange analysis, bromodeoxyuridine $(10 \mu \mathrm{g} / \mathrm{ml})$ was added at the beginning of the culture. ${ }^{[4]}$ Cell cycle kinetics was studied by the BrdU-Harlequin technique using the replication index (RI) calculated by the standard formula. ${ }^{[5]}$ The Student ' $P$-test was used for statistical analysis using 'Statistica' software (StatSoft, Inc.).

In this study, cisplatin was tested in vitro in human lymphocytes for its toxicity potential using chromosomal aberrations, sister chromatid exchanges, and cell cycle kinetics as parameters, and it was found to be genotoxic only when activated metabolically in the presence of S9 mix [Tables 1 and 2]. This means that cisplatin can be genotoxic

Table 1: Protective action of genistein and gingerol on chromosomal aberrations induced by cisplatin

\begin{tabular}{|c|c|c|c|c|c|c|c|c|}
\hline \multirow[t]{2}{*}{ Concentration } & \multicolumn{3}{|c|}{ Abnormal cells } & \multicolumn{5}{|c|}{ Chromosomal aberrations } \\
\hline & With gaps & Without gaps & CAs $/$ Cell \pm SE & Gaps & CTB & CSB & CTE & DIC \\
\hline \multicolumn{9}{|l|}{ Cisplatin $(\mu \mathrm{g} / \mathrm{ml})$} \\
\hline 1.5 & 24 & 20 & $0.20 \pm 0.03^{\mathrm{a}}$ & 9 & 10 & 4 & 1 & - \\
\hline 2.5 & 29 & 25 & $0.25 \pm 0.04^{\mathrm{a}}$ & 10 & 13 & 4 & 1 & 1 \\
\hline \multicolumn{9}{|l|}{ Genistein $(\mu \mathrm{M})$} \\
\hline 25 & 3 & 2 & $0.02 \pm 0.01$ & 1 & 2 & - & - & - \\
\hline 40 & 2 & 1 & $0.01 \pm 0.01$ & 1 & 1 & - & - & - \\
\hline \multicolumn{9}{|l|}{ Genistein+Cisplatin } \\
\hline $25+1.5$ & 17 & 13 & $0.13 \pm 0.03^{\mathrm{ab}}$ & 6 & 9 & 2 & - & - \\
\hline $25+2.5$ & 23 & 19 & $0.19 \pm 0.04^{\mathrm{ab}}$ & 7 & 11 & 3 & 1 & 1 \\
\hline $40+1.5$ & 11 & 7 & $0.07 \pm 0.01^{\mathrm{ab}}$ & 4 & 5 & 2 & - & - \\
\hline $40+2.5$ & 15 & 10 & $0.10 \pm 0.02^{\mathrm{ab}}$ & 5 & 9 & 1 & - & - \\
\hline \multicolumn{9}{|l|}{ Gingerol $(\mu \mathrm{M})$} \\
\hline 15 & 2 & 1 & $0.01 \pm 0.01$ & 1 & 1 & - & - & - \\
\hline 25 & 3 & 2 & $0.02 \pm 0.02$ & 1 & 2 & - & - & - \\
\hline \multicolumn{9}{|l|}{ Gingerol+cisplatin } \\
\hline $15+1.5$ & 11 & 9 & $0.09 \pm 0.03^{\mathrm{ab}}$ & 4 & 6 & 1 & - & - \\
\hline $15+2.5$ & 15 & 12 & $0.12 \pm 0.04^{\mathrm{ab}}$ & 5 & 7 & 3 & - & - \\
\hline $25+1.5$ & 6 & 4 & $0.04 \pm 0.02^{\mathrm{ab}}$ & 2 & 3 & 1 & - & - \\
\hline $25+2.5$ & 9 & 6 & $0.06 \pm 0.03^{\mathrm{ab}}$ & 3 & 5 & 1 & - & - \\
\hline $\begin{array}{l}\text { Negative control } \\
(\mathrm{DMSO}, 0.5 \mu \mathrm{l} / \mathrm{ml})\end{array}$ & 2 & 1 & $0.01 \pm 0.01$ & 1 & 1 & - & - & - \\
\hline Positive control (CP) & 52 & 38 & $0.38 \pm 0.05^{\mathrm{a}}$ & 18 & 22 & 7 & 4 & 1 \\
\hline Untreated & 3 & 2 & $0.02 \pm 0.01$ & 1 & 2 & - & - & - \\
\hline
\end{tabular}

SE: Standard error; CTB: Chromatid break; CSB: Chromosome break; CTE: Chromatid exchange; DIC: Dicentric; DMSO: Dimethyl sulphoxide; CP: Cyclophosphamide;

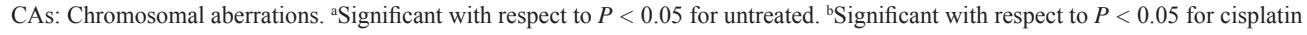


Table 2: Protective action of genistein and gingerol on cell cycle kinetics and cisplatin-induced sister chromatid exchanges

\begin{tabular}{lcc}
\hline Concentration & $\begin{array}{c}\text { SCEs/ } \\
\text { Cell } \pm \text { SE }\end{array}$ & $\begin{array}{c}\text { Replication } \\
\text { index }\end{array}$ \\
\hline Cisplatin $(\mu \mathrm{g} / \mathrm{ml})$ & $15.34 \pm 0.77^{\mathrm{a}}$ & $1.25^{\mathrm{a}}$ \\
1.5 & $16.32 \pm 0.81^{\mathrm{a}}$ & $1.29^{\mathrm{a}}$ \\
2.5 & $1.53 \pm 0.22$ & \\
Genistein $(\mu \mathrm{M})$ & $1.55 \pm 0.25$ & 1.67 \\
25 & & 1.70 \\
40 & $12.67 \pm 0.85^{\mathrm{ab}}$ & \\
Genistein+cisplatin & $13.45 \pm 0.78^{\mathrm{ab}}$ & $1.59 \mathrm{a}^{\mathrm{b}}$ \\
$25+1.5$ & $10.21 \pm 0.64^{\mathrm{ab}}$ & $1.47 \mathrm{a}^{\mathrm{b}}$ \\
$25+2.5$ & $11.14 \pm 0.61^{\mathrm{ab}}$ & $1.65 \mathrm{a}^{\mathrm{b}}$ \\
$40+1.5$ & & $1.68 \mathrm{a}^{\mathrm{b}}$ \\
$40+2.5$ & $1.45 \pm 0.19$ & \\
Gingerol $(\mu \mathrm{M})$ & $1.47 \pm 0.21$ & 1.56 \\
15 & & 1.59 \\
25 & $9.34 \pm 0.67^{\mathrm{ab}}$ & \\
Gingerol+cisplatin & $11.28 \pm 0.63^{\mathrm{ab}}$ & $1.63^{\mathrm{ab}}$ \\
$15+1.5$ & $12.33 \pm 0.57^{\mathrm{ab}}$ & $1.58^{\mathrm{ab}}$ \\
$15+2.5$ & $10.14 \pm 0.55^{\mathrm{ab}}$ & $1.69^{\mathrm{ab}}$ \\
$25+1.5$ & $1.45 \pm 0.12$ & $1.64^{\mathrm{ab}}$ \\
$25+2.5$ & & 1.55 \\
Negative control & $20.73 \pm 0.89^{\mathrm{a}}$ & $1.33^{\mathrm{a}}$ \\
(DMSO, $0.5 \mu 1 / \mathrm{ml})$ & $1.22 \pm 0.10$ & 1.72 \\
Positive control $(\mathrm{CP})$ & & \\
Untreated & & \\
\hline
\end{tabular}

SE: Standard error; DMSO: Dimethyl sulphoxide; CP: Cyclophosphamide;

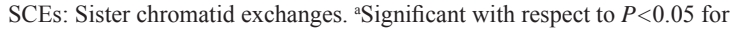

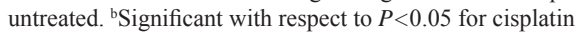

only when combined with metabolic agents during chemotherapy and not in the case of single treatment. Therefore, the combination of drugs should be carefully selected in order to avoid the toxicity of cisplatin. Another way of avoiding or reducing the toxicity of cisplatin is by combining it with free radical scavenging agents. ${ }^{[1]}$

Genistein and gingerol were combined with cisplatin at selected doses to possibly ameliorate the genotoxicity induced by cisplatin in the presence of a metabolic activation system. The two antioxidants proved to be very effective in reducing the genotoxicity caused by cisplatin when each was combined separately with cisplatin. Genistein and gingerol assist in preventing reactive oxygen species damage by scavenging free radicals that are produced by genotoxic agents. ${ }^{[6,7]}$

This study reveals that cisplatin has the potential to be genotoxic in cultured human lymphocyte chromosomes at 1.5 and $2.5 \mu \mathrm{g} / \mathrm{ml}(P<0.05)$, and the toxicity of cisplatin is reduced considerably, possibly because of the free radical scavenging activity of genistein and gingerol. Gingerol has greater potential to ameliorate genotoxicity compared to genistein. Chemotherapy leads to the complication of secondary cancers. Antioxidants in diet could protect patients undergoing chemotherapy as shown by studies where antioxidants were combined with chemotherapeutic drugs that increased growth-inhibition of chemotherapeutic agents on cancers. ${ }^{[8]}$ Cancer cells and normal cells are different, which helps antioxidant complementary therapy protect the normal tissues from damage due to chemotherapeutic agents without compromising therapeutic effectiveness. ${ }^{[8]}$ It is concluded that the toxicity of cisplatin could be significantly reduced by combining cisplatin and antioxidants during chemotherapy to minimize the risk of secondary tumors. Anticancer drugs could be developed further commercially from antioxidants like genistein and gingerol.

\section{Beg $\mathrm{T}^{1,2}$, Siddique $\mathrm{YH}^{1}$, Afzal $\mathrm{M}^{1}$}

\author{
${ }^{\prime}$ Human Genetics and Toxicology Laboratory, Section \\ of Genetics, Department of Zoology, Aligarh Muslim \\ University, Aligarh, Uttar Pradesh, India, ${ }^{2}$ Biology \\ Department, Jazan University, Jazan, Saudi Arabia
}

Address for correspondence: Dr. Tanveer Beg; E-mail:tan.beg@gmail.com

\section{REFERENCES}

1. Ali BH, Al Moundhri MS. Agents ameliorating or augmenting the nephrotoxicity of cisplatin and other platinum compounds: A review of some recent research. Food Chem Toxicol 2006;44:1173-83.

2. Beg T, Siddique YH, Ara G, Gupta J, Afzal M. Antigenotoxic effect of genistein and gingerol on genotoxicity induced by norethandrolone and oxandrolone in cultured human lymphocytes. Int J Pharmacol 2008;4: 177-83.

3. Carballo MA, Alvarez S, Boveris A. Cellular stress by light and Rose Bengal in human lymphocytes. Mutat Res 1993;288:215-22.

4. Perry P, Wolff S. New giemsa method for differential staining of sister chromatids. Nature 1974;251:156-8.

5. Ivett JL, Tice RR. Average generation time: A new method of analysis and quantitation of cellular proliferation kinetics. Environ Mutagen1982;4:358

6. Foti P, Erba D, Riso P, Spadafranca A, Criscuoli F, Testolin G. Comparison between daidzein and genistein antioxidant activity in primary and cancer lymphocytes. Arch Biochem Biophys 2005;433:421-7.

7. Kikuzaki H, Nakatani N. Antioxidant effects of some ginger constituents. J Food Sci 1993;58:1407-10.

8. Blaylock RL. A review of conventional cancer prevention and treatment and the adjunctive use of neutraceutical supplements and antioxidants: Is there a danger or a significant benefit? J Am Neutraceut Ass 2000;3:75-95.

\begin{tabular}{|l|l|}
\hline \multicolumn{2}{|c|}{ Access this article online } \\
\hline Quick Response Code: & Website: \\
\hline & www.jyoungpharm.in \\
& \\
\hline
\end{tabular}

